\title{
Quantitative ICP-OES Determination of Trace and Essential Elements in the Plant Species of Genus Ferula
}

\author{
Sermin Yelkenci ${ }^{a}$, Huseyin Altundag*, Mehmet Sagiroglu ${ }^{\mathrm{b}}$, and Abdul Razaque Memon ${ }^{\mathrm{c}}$ \\ ${ }^{a}$ Sakarya University, Faculty of Arts and Sciences, Department of Chemistry, \\ 54187 Sakarya, Turkey \\ b Sakarya University, Faculty of Arts and Sciences, Department of Biology, \\ 54187 Sakarya, Turkey \\ ${ }^{\mathrm{c}}$ International University of Sarajevo, Faculty of Engineering and Natural Sciences, \\ 71000, Sarajevo, BiH
}

\section{INTRODUCTION}

Apiaceae is a family of aromatic plants that constitutes approximately 3,700 species spread across 434 genera. The genus ferula (Apiaceae) contains 180-185 species with the highest diversity in central and southwest Asia. It has about 130 species, around 100 of which are endemic (1). In Turkey, the first investigation on ferula was carried out by Pesmen (2) who identified 18 species, one of which was known and nine of them were endemic. Four new species have since been added to the flora of Turkey $(3,4,5)$ and additionally one of the previously known species was redescribed by Sarıglu, and Duman, (6). Around 55\% of the Turkish species (12 of 22 in total) are endemic, showing that Turkey is possibly one of the major gene centres of this genus. The Turkish ferula species are monocarpic or polycarpic herbaceous perennial plants growing up to a height of $20-500 \mathrm{~cm}$, with hollow stems. The leaves are tri-seven pinnate, with generally stout basals heath clasping the stem. The flowers are yellow, with or without reduced sepals in large umbels. Mericarps are dorsally compressed with generally 1-3 vittae pervallecula on the dorsal surface.

Species of the genus ferula are usually referred to as "Caksir" in Turkish and are used today as a tonic (aphrodisiac), germicide,

*Corresponding author.

:E-mail: altundag@sakarya.edu.tr

\section{ABSTRACT}

Some of the species belonging to the genus ferula are known to be used as traditional medicine for treating various diseases in South Asia, the Middle East, and in North Africa. In this study, samples from 20 varieties of plants belonging to 20 species of the genus ferula L. (Apiaceae) were collected from various regions of Turkey. After air drying, the samples were solubilized by using the microwave dissolution technique. The concentration levels of the different elements (Al, B, Ba, Cr, Cu, Fe $\mathrm{Mn}, \mathrm{Ni}, \mathrm{Pb}, \mathrm{Sb}, \mathrm{Se}, \mathrm{Sr}$, and $\mathrm{Zn}$ ) were determined by ICP-OES. The accuracy of the proposed method was verified by analyzing certified reference materials SRM 1573a Tomato and INCT-TL-1 Tea Leaves. The results showed a significant variation of elemental content, especially for $\mathrm{Al}, \mathrm{B}, \mathrm{Ba}$, and $\mathrm{Fe}$ amongst the fruit- and flower-bearing plants of the different plant species of the same genus. This clearly indicates that each plant species has a different absorption and accumulation capacity for different metals. Further work on the accumulation of these metals in the leaves and shoots of the plants is in progress

constipation relaxant, an antitussive antidote against poisoning as well as an agent for treatment of hemorrhoids and urinary tract diseases. Moreover, they are also used as a nutrient and an animal feed in different regions of Turkey and are widely consumed in the vicinity of Erzurum, Van (East Anatolia), Hatay, Osmaniye, Kahramanmaras (South Anatolia), Nigde, and Malatya (Central Anatolia).

Certain mineral elements that are non-toxic and necessary for human health may exhibit toxic effects if taken in high quantities or for a long period of time (7). The heavy metal content in commercial products has particularly increased in recent years. Also, high concentrations in edible plants are a threat to human health (8) because these metals accumulate in the body through inhalation, ingestion, and skin absorption $(9,10)$. On the other hand, the elements of this study (Al, B, Ba, Cr, Cu, Fe, Mn, Ni, $\mathrm{Pb}, \mathrm{Sb}, \mathrm{Se}, \mathrm{Sr}$, and $\mathrm{Zn}$ ), which are in the second row in the periodic table, may also lead to various diseases if their intake is insufficient. Therefore, it is necessary to classify these plant species according to their metal content in order to use appropriate material for herbal medicine.

The aim of this study was to determine the metal composition of these important plant species and to determine the levels in the different parts of the plants used for natural herbal medicine. For this study, 20 varieties of plants belonging to the genus ferula (Apiaceae), collected from various regions of Turkey, were first solubilized by microwave dissolution technique, then the concentrations of $\mathrm{Al}, \mathrm{B}$, $\mathrm{Ba}, \mathrm{Cr}, \mathrm{Cu}, \mathrm{Fe}, \mathrm{Mn}, \mathrm{Ni}, \mathrm{Pb}, \mathrm{Sb}, \mathrm{Se}, \mathrm{Sr}$, and $\mathrm{Zn}$ in these plants determined by ICP-OES. This study is important, 
because there is no reported data available regarding the trace metal content in these medicinal plants.

\section{EXPERIMENTAL}

\section{Instrumentation}

In order to solubilize the plant samples, a Milestone Ethos D microwave closed system (maximum pressure $1450 \mathrm{psi}$, maximum temperature $300{ }^{\circ} \mathrm{C}$ ) (Milestone, Italy) was used. A Spectro Arcos model 165 inductively coupled plasma optical emission spectrometer (ICP-OES) was used for the determination of all elements (Spectro Analytical Instruments, Kleve, Germany). The instrumental operating conditions are listed in Table I.

\section{Standard Solutions and Reagents}

A $10 \% \mathrm{HNO}_{3}$ solution was used for cleaning the glass and plastic containers used for the study. The containers were allowed to stand in $10 \% \mathrm{HNO}_{3}$ solution for 1 day before being rinsed with Milli-Q ${ }^{\circledR}$ ultra-distilled water $(18.2 \mathrm{M} \Omega \cdot \mathrm{cm})$ (Millipore Corporation, USA) and used thereafter. Suprapur ${ }^{\circledR}$ nitric acid $(65 \%, w / w)$ and analytical grade hydrogen peroxide $(30 \%$, w/w) were purchased from Merck (Germany). An ICP multi-element standard solution of $1000 \mathrm{mg} \mathrm{L}^{-1}$, as the calibration standard, was diluted to the desired concentrations using ultra-distilled water. The accuracy of the proposed method was evaluated by analzying certified reference materials of SRM 1573a Tomato (National Institute of Standards and Technology, Gaithersbur, MD, USA) and and INCT-TL-1 Tea Leaves (Institute of Nuclear Chemistry and Technology, Warsaw, Poland).

\section{Analysis of Reference Materials}

The concentrations of $\mathrm{Al}, \mathrm{B}, \mathrm{Ba}$, $\mathrm{Cr}, \mathrm{Cu}, \mathrm{Fe}, \mathrm{Mn}, \mathrm{Ni}, \mathrm{Pb}, \mathrm{Sb}, \mathrm{Se}, \mathrm{Sr}$, and $\mathrm{Zn}$ were determined using the certified reference materials SRM 1573a Tomato Leaves and INCT-TL-1 Tea Leaves. It can be seen from Table II that the results are compatible with the certified values, and proves the validity of the method used for the plant samples.

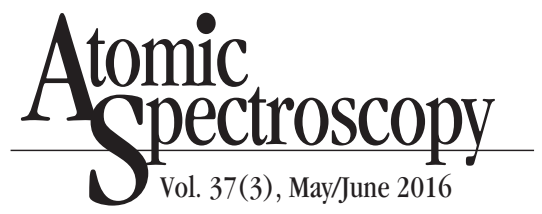

Sample Collection and Pretreatment

The floral parts of $F$. tingitana, F. Lycia, $F$. duranii ve meyveli kisimlarda $F$. szowitsiana, $F$. orientalis, F. tingitana, F. duranii, F. Lycia plant specimens were

TABLE I

ICP-OES Instrumental Operating Conditions

\begin{tabular}{ll}
\hline Instrument & Spectro Arcos 165 ICP-OES \\
Viewing Height & $12 \mathrm{~mm}$ \\
Wavelengths & Al: $176.641 \mathrm{~nm}, \mathrm{~B}: 182.527 \mathrm{~nm}, \mathrm{Ba}: 45$ \\
& $\mathrm{Co:} 230.786 \mathrm{~nm}, \mathrm{Cr}: 267.716 \mathrm{~nm}, \mathrm{Cu}: 3$ \\
& Fe: $238.204 \mathrm{~nm}, \mathrm{Mn}: 257.611 \mathrm{~nm}, \mathrm{Ni}$ \\
& $\mathrm{Pb}: 220.353 \mathrm{~nm}, \mathrm{Sr}: 407.771 \mathrm{~nm}, \mathrm{Zn}$ : \\
& 3 \\
Replicates & $1450 \mathrm{~W}$ \\
RF Power & Cyclonic \\
Spray Chamber & Modified Lichte Nebulizer \\
Nebulizer & $0.8 \mathrm{~L} / \mathrm{min}$ \\
Nebulizer Flow Rate & Quartz, fixed, 3.0 mm Injector Tube \\
Plasma Torch & $50 \mathrm{sec}$ per Replicate \\
Replicate Read Time & $13 \mathrm{~L} / \mathrm{min}$ \\
Plasma Gas Flow & $0.7 \mathrm{~L} / \mathrm{min}$ \\
Auxiliary Gas Flow & $2.0 \mathrm{~mL} / \mathrm{min}$ \\
Sample Aspiration Rate & $25 \mathrm{rpm}$ \\
Sample Pump Rate &
\end{tabular}

TABLE II

Comparasion of Results for Certified Standard Materials and the Proposed Study $(\mathrm{N}=3)$

\begin{tabular}{|c|c|c|c|c|c|c|}
\hline \multicolumn{7}{|c|}{ Concentration $\left(\mu \mathrm{g} \mathrm{g}^{-1}\right)$} \\
\hline \multirow{2}{*}{$\begin{array}{l}\text { Ele- } \\
\text { ments }\end{array}$} & \multicolumn{3}{|c|}{ TEA LEAVES (INCT-TL-1) } & \multicolumn{3}{|c|}{ TOMATO LEAVES $1573 \mathrm{a}$} \\
\hline & $\begin{array}{l}\text { Certifited } \\
\text { Value }\end{array}$ & $\begin{array}{l}\text { This } \\
\text { Study }\end{array}$ & $\begin{array}{l}\text { Recovery } \\
(\%)\end{array}$ & $\begin{array}{l}\text { Certifited } \\
\text { Value }\end{array}$ & $\begin{array}{l}\text { This } \quad R \\
\text { Study }\end{array}$ & $\begin{array}{c}\text { Recovery } \\
(\%)\end{array}$ \\
\hline $\mathrm{Al}$ & $0.229 \pm 0.228$ & $0.218 \pm 0.197$ & 95 & $598 \pm 12$ & $580 \pm 8$ & 97 \\
\hline B & - & - & - & $33.3 \pm 0.7$ & $31.4 \pm 0.4$ & 95 \\
\hline $\mathrm{Ba}$ & $43.2 \pm 3.9$ & $41.5 \pm 2.8$ & 96 & - & - & - \\
\hline Co & $0.387 \pm 0.042$ & $0.368 \pm 0.039$ & 95 & $0.57 \pm 0.02$ & $0.54 \pm 0.01$ & 92 \\
\hline $\mathrm{Cr}$ & $1.91 \pm 0.22$ & $1.98 \pm 0.25$ & 94 & $1.99 \pm 0.06$ & $1.89 \pm 0.05$ & 94 \\
\hline $\mathrm{Cu}$ & $20.4 \pm 1.5$ & $19.9 \pm 1.1$ & 98 & $4.70 \pm 0.14$ & $4.65 \pm 0.09$ & 95 \\
\hline $\mathrm{Fe}$ & - & - & - & $368 \pm 7$ & $361 \pm 6$ & 99 \\
\hline $\mathrm{Mn}$ & $0.157 \pm 0.011$ & $0.149 \pm 0.009$ & 95 & $246 \pm 8$ & $234 \pm 4$ & 98 \\
\hline $\mathrm{Ni}$ & $6.12 \pm 0.52$ & $5.94 \pm 0.48$ & 97 & $1.59 \pm 0.07$ & $1.54 \pm 0.04$ & 95 \\
\hline $\mathrm{Pb}$ & $1.78 \pm 0.24$ & $1.71 \pm 0.29$ & 96 & - & - & 97 \\
\hline $\mathrm{Sr}$ & $20.8 \pm 1.7$ & $19.8 \pm 1.5$ & 95 & - & - & 95 \\
\hline $\mathrm{Zn}$ & $34.7 \pm 2.7$ & $34.0 \pm 2.6$ & 98 & $30.9 \pm 0.7$ & $29.9 \pm 0.3$ & 97 \\
\hline
\end{tabular}

BDL, below the detection limit. 
taken from different locations (Table III). The samples from the taxa belonging to the genus ferula were collected from different regions in Turkey in the form of either the flower or the fruit.

The collected plant samples were dried and turned into herbarium materials, then allowed to stand at $-20{ }^{\circ} \mathrm{C}$ for 2 days in order to remove any insects and insect eggs. The fruit-bearing parts of the plants were ovendried at $105^{\circ} \mathrm{C}$ for 150 minutes and then again for thefruit-bearing parts at $105^{\circ} \mathrm{C}$ for 60 minutes. The dried fruit- and flower-bearing parts were homogenized in a porcelain mortar and

TABLE III Samples from Genus Ferula Collected at Different Regions in Turkey

Genus of Flower- Genus of Fruitbearing Samples bearing Samples

F. elaeochytris $\quad$ F. brevipedicellata

F. haussknechtii F. elaeochytris

$\begin{array}{ll}\text { F. tenuissima } & \text { F. tingitana }\end{array}$

$\begin{array}{ll}\text { F. communis } \quad \text { F. hermonis } & \text {. }\end{array}$

F. tingitana F. haussknechtii

F. duranii F. duranii

$\begin{array}{ll}\text { F. rigidula } & \text { F. halophila }\end{array}$

$\begin{array}{ll}\text { F. durudeana } & \text { F. tenuissima }\end{array}$

F. brevipedicellata F. parva

F. lycia F. szowitsiana

F. huber-morathii F. orientalis

F. mervynii $\quad$ F. lycia

F. longipedunculata F. communis

$\begin{array}{ll}\text { F. tingitana } & \text { F. halophila }\end{array}$

$\begin{array}{ll}\text { F. caspica } & \text { F. szowitsiana }\end{array}$

$\begin{array}{ll}\text { F. lycia } & \text { F. orientalis }\end{array}$

F. anatolica F. tingitana

F. orientalis F. duranii

F. hermonis F. rigidula

F. duranii $\quad$ F. lycia

F. parva $\quad$ F. caspica

F. szowitsiana $\quad$ F. huber-morathii

F. halophila $\quad$ F. anatolica

F. mervynii

F. durudeana

F. longipeduncuata stored in polyethylene bags at room temperature until the day of analysis. After solubilizing by microwave dissolution, the fruit- and flowerbearing parts of the plant samples were analyzed for trace and essential elements using ICP-OES.

\section{Microwave Digestion of Samples}

For microwave digestion, $0.25 \mathrm{~g}$ of the reference material and $1 \mathrm{~g}$ of the plant sample were taken and studied in duplicate. A 6-mL amount of $65 \% \mathrm{HNO}_{3}$ and $2 \mathrm{~mL}$ of $30 \%$

$\mathrm{H}_{2} \mathrm{O}_{2}$ was added to the samples and digested in the microwave oven.

\begin{tabular}{|c|c|c|c|}
\hline \multicolumn{4}{|c|}{$\begin{array}{c}\text { TABLE IV } \\
\text { Operating Conditions } \\
\text { for Samples in } \\
\text { Microwave Digestion System }\end{array}$} \\
\hline Steps & $\begin{array}{l}\text { Time } \\
(\min )\end{array}$ & $\begin{array}{l}\text { Power } \\
\text { (W) }\end{array}$ & $\begin{array}{l}\text { Temp. } \\
\left({ }^{\circ} \mathrm{C}\right)\end{array}$ \\
\hline 1 & 2 & 250 & 100 \\
\hline 2 & 2 & 250 & 100 \\
\hline 3 & 5 & 300 & 120 \\
\hline 4 & 5 & 550 & 170 \\
\hline 5 & 6 & 700 & 200 \\
\hline \multicolumn{4}{|c|}{ Vent for 12 minutes } \\
\hline
\end{tabular}

TABLE V

Daily Tolerable Amount for Elements (Flower-bearing Part / Fruit-bearing Part)

\begin{tabular}{ccccc}
\hline & \multicolumn{2}{c}{ Flower-bearing Part } & \multicolumn{2}{c}{ Fruit-bearing Part } \\
\hline Element & $\begin{array}{c}\text { Min. Value } \\
\left(\mu \mathrm{g} \mathrm{g}^{-1}\right)\end{array}$ & $\begin{array}{c}\text { Max. Value } \\
\left(\mu \mathrm{g} \mathrm{g}^{-1}\right)\end{array}$ & $\begin{array}{c}\text { Min. Value } \\
\left(\mu \mathrm{g} \mathrm{g}^{-1}\right)\end{array}$ & $\begin{array}{c}\text { Max. Value } \\
\left(\mu \mathrm{g} \mathrm{g}^{-1}\right)\end{array}$ \\
\hline $\mathrm{Al}$ & 9.20 & 717.20 & 7.80 & 498.70 \\
$\mathrm{~B}$ & 29.60 & 143.00 & 6.10 & 100.90 \\
$\mathrm{Ba}$ & 1.00 & 34.30 & 1.00 & 78.80 \\
$\mathrm{Cr}$ & 0.54 & 3.10 & 0.10 & 0.94 \\
$\mathrm{Cu}$ & 6.90 & 29.30 & 1.20 & 11.20 \\
$\mathrm{Fe}$ & 40.30 & 638.20 & 16.90 & 446.30 \\
$\mathrm{Mn}$ & 12.50 & 55.00 & 4.50 & 24.20 \\
$\mathrm{Ni}$ & 0.40 & 11.40 & 0.10 & 0.89 \\
$\mathrm{~Pb}$ & 0.50 & 4.40 & 0.07 & 0.89 \\
$\mathrm{Sb}$ & 2.60 & 7.80 & 0.01 & 6.20 \\
$\mathrm{Se}$ & 1.00 & 10.00 & 0.01 & 4.90 \\
$\mathrm{Sr}$ & 2.20 & 146.00 & 5.50 & 169.20 \\
$\mathrm{Zn}$ & 19.60 & 120.60 & 1.70 & 34.70 \\
\hline
\end{tabular}

After completion of the procedure, the digested samples were diluted to a volume of $25 \mathrm{~mL}$ with ultrapure distilled water. The digestion conditions for the microwave system are given in Table IV.

\section{RESULTS AND DISCUSSION}

The trace element concentrations of the fruit- and flower-bearing plants of 21 plant species are given in Figures 1 and 2, respectively.

The quantities of trace elements in the human body have been previously reported (11). The daily amount of aluminium per $\mathrm{kg}$ received from food by a healthy individual weighing $70 \mathrm{~kg}$ on average is $0.01-1.4 \mathrm{mg}$ (11). Figures 1 and 2 show that the trace elemental content of both fruit- and flowerbearing plants are much higher in some species than the daily elemental level required per person.

The daily tolerable amount of elements vs. the amount found in the flower- and fruit-bearing plants for an individual weighing $60 \mathrm{~kg}$ are listed in Table V. 

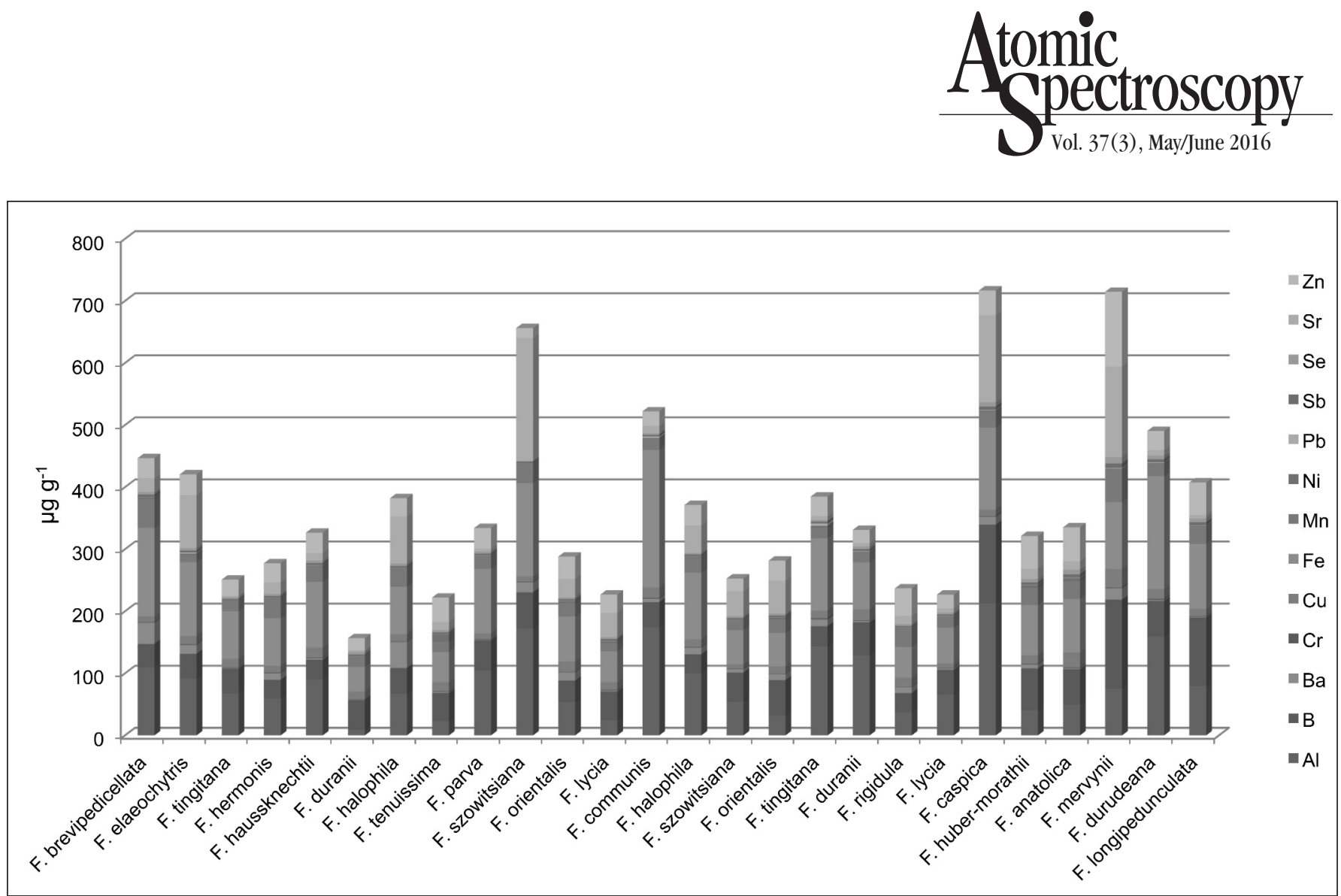

Fig. 1. Determination of trace element levels of fruit-bearing parts of plants by ICP-OES.

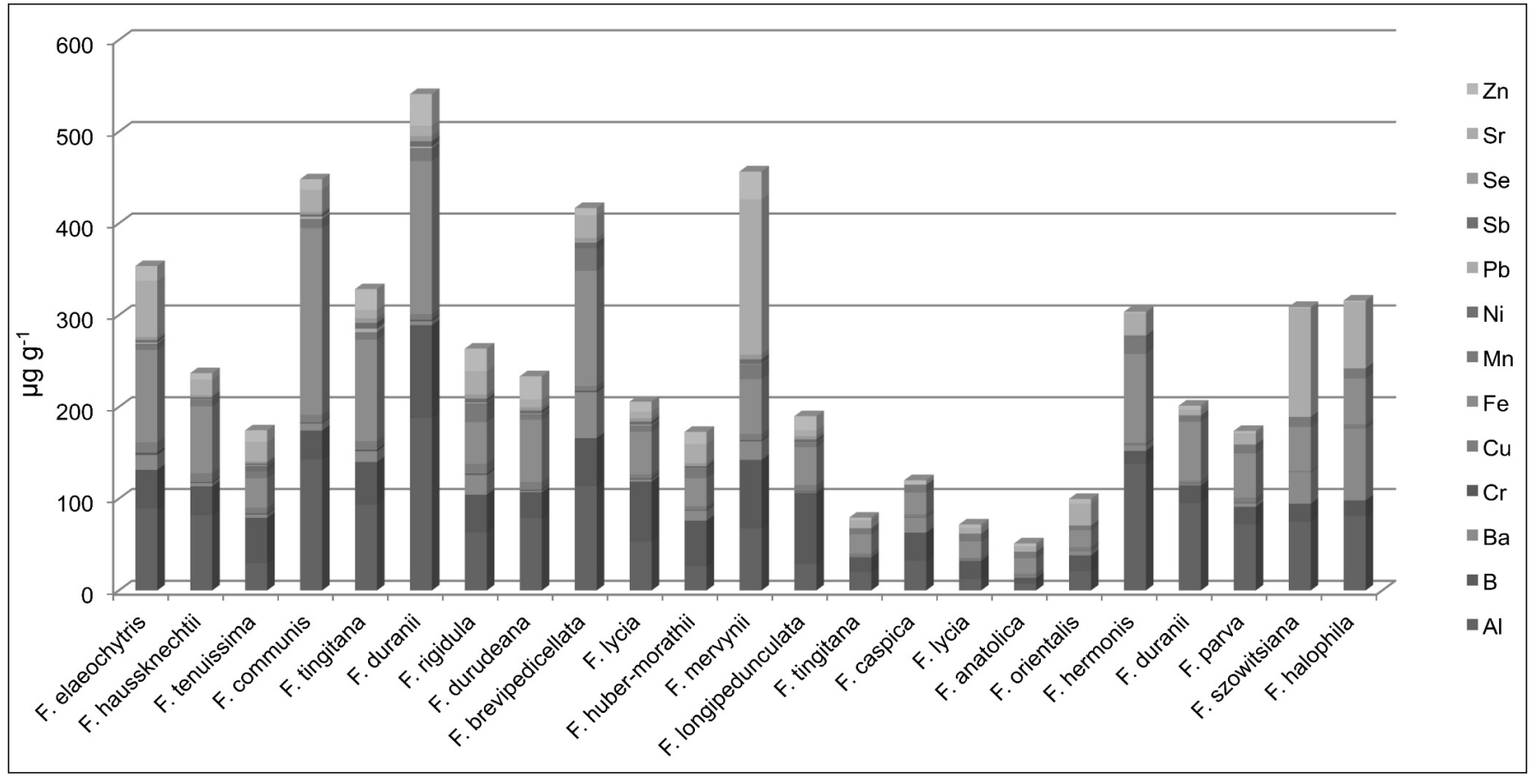

Fig. 2. Determination of trace element levels in flower-bearing parts of plants by ICP-OES. 


\section{Boron}

For boron, the average daily amount recommended for a healthy individual weighing around $60 \mathrm{~kg}$ is 10-20 mg (12). It can be seen that the boron content in all fruit-bearing parts of the plants is above this value, except that the flower-bearing parts of $F$. anatolica are below this value.

\section{Barium}

The daily recommended intake of barium for an individual weighing around $60 \mathrm{~kg}$ through food and drink is $1.24 \mathrm{mg}$ (13). The fruitbearing parts of $F$. Tingitana (Ödemis), F. Duranii (Antalya, Akseki Çukurköy), F. parva and $F$. longipedunculata as well as the flower-bearing parts of $F$. long $i$ pedunculata, F. Tingitana (Ödemis), F. Lycia (Konya, Hadim) and $F$. anatolica have lower quantities of barium.

\section{Chromium}

For chromium, the daily recommended intake for an individual weighing around $60 \mathrm{~kg}$ is $50-200$ $\mu \mathrm{g}$ (14). It was found that the results for fruit- and flower-bearing parts of the plants are above this value.

\section{Copper}

For copper, the daily recommended intake for an individual weighing around $60 \mathrm{~kg}$ is $3 \mathrm{mg}$ (15). The fruit-bearing parts of the plants showed $\mathrm{Cr}$ at above this value, whereas the flower-bearing parts generally showed results close to this value.

\section{Iron}

For iron, the daily recommended intake for a healthy individual weighing around $60 \mathrm{~kg}$ was established as $48 \mathrm{mg}$ (15). Only fruitbearing parts of F. Durani (Antalya, Akseki Çukurköy) showed a lower value, while some of the flowerbearing parts were above this value and some others below this value.

\section{Manganese}

The daily tolerated intake of manganese for an individual weighing around $60 \mathrm{~kg}$ is in the range of $2-9$ mg (16). The results showed that the amount of this element in fruit-bearing parts of the plants is above this value and is also quite high for flower-bearing parts.

\section{Nickel}

For nickel, the daily recommended amount for a healthy individiual weighing around $60 \mathrm{~kg}$ was established as 100-300 $\mu \mathrm{g}$ (16). The results for the fruit-bearing parts of the plants are above this value, whereas some of the results for flower-bearing parts are below this range.

\section{Lead}

The daily tolerated intake of lead for an individual weighing around $60 \mathrm{~kg}$ on average is $3.57 \mathrm{mg}$ (17). Only fruit- and flower-bearing parts of $F$. tingitana (Efes harabeleri) showed higher values.

\section{Antimony}

The daily tolerated intake of antimony for an individual weighing around $60 \mathrm{~kg}$ is $6 \mathrm{mg}$ (18). Food usually contains small amounts of antimony. One can eat and drink about 5 micrograms ( 5 millionths of a gram) of antimony every day.

\section{Selenium}

The daily recommended intake of selenium established by the National Research Council (USA) is $0.5 \mathrm{mg}$. All the results for fruitbearing parts of the plants are below this value, whereas some of the values for flower-bearing parts are above and some are below this value.

\section{Strontium}

For strontium, an individual can tolerate a daily intake of $2-4 \mathrm{mg}$ from a normal diet of grain and vegetables (19). Only fruit-bearing parts of $F$. Tingitana (Ödemiş) showed values in this range, while the flower-bearing parts of all plants show values above this range.

\section{Zinc}

The daily tolerated intake of zinc for a healthy individual weighing around $60 \mathrm{~kg}$ was established as $60 \mathrm{mg}$ (15). Only fruit-bearing parts of $F$. mervynii have values above, while flower-bearing parts of all plants have values below this range.

The above evaluation of the various elments and their recommended vs. tolerable values give an indication that before using any of the plant parts for herbal medicinal use, the elemental content should be studied before formulating a dosage for human consumption.

\section{CONCLUSION}

In the following plants used as medicinal herbs and belonging to the ferula gene, the concentrations of $\mathrm{Al}, \mathrm{B}, \mathrm{Ba}, \mathrm{Cr}, \mathrm{Cu}, \mathrm{Fe}, \mathrm{Mn}, \mathrm{Ni}, \mathrm{Pb}$, $\mathrm{Sb}, \mathrm{Se}, \mathrm{Sr}$, and $\mathrm{Zn}$ in their flowerand fruit-bearing parts were studied: $F$. anatolica, F. arevipedicellata, F. caspica, F. communis, F. durani, F. drudeana, F. elaeochytris, F. balophila, F. haussknechti, F. bermonis, F. buber-moratbii, F. longipedunculata, F. lycia, F. mervynii, $F$. orientalis, $F$. parva, $F$. rigidula, F. szowitsiana, F. tenuissima, F. tingitana. Furthermore, fruitbearing parts of F. durani, F. communis, F. lycia, F. orientalis, F. szowitsiana, F. tingitana species and flower-bearing parts of F. durani, F. lycia, and F. tingitana.

The results of this study indicate that the elemental range in the plant parts were normal and that these plant parts can be safely used for medicinal purposes. People are exposed to heavy metals in a variety of ways, including by respiration, skin absorption, and nutrition. The metals in these plants do not 


\section{Atomic $_{\text {Spectroscopy }}^{\text {to }}$ \\ 1 Vol. 37(3), May/June 2016}

show toxic effects below certain threshold quantities; however, they can become harmful for the human metabolism when taken in excess. Therefore, today, it is important to have knowledge about the metal concentrations in the ferula genus taxa utilized as a tonic (aphrodisiac), germicide, constipation relaxant, an antidote against poisoning, antitussive and animal feed, as well as an agent for treatment of hemorrhoids and urinary tract disorders.

\section{ACKNOWLEDGMENT}

This work was supported by the Sakarya University Research Fund under Project Number 2012-50-02021. This work was performed partly at the International University of Sarajevo, Faculty of Engineering and Natural Sciences, Sarajevo, BIH. The authors also thank Prof. Dr. Fuat Gurcan (Faculty Dean, International University of Sarajevo, Faculty of Engineering and Natural Sciences, Sarajevo, BiH) for his valuable advice during this study.

Received March 3, 2015.

\section{REFERENCES}

1. M.G. Pimenov and M.V. Leonov, Turkish J. of Botany 28, 139 (2004).

2. H. Pesmen, Flora of Turkey and the East Aegean Islands, Vol. 4. Edinburgh, U.K.: Edinburgh University Press, 440-453 (1972).

3. H. Duman and M. Sagiroglu, Botanical J. of the Linnean Society 147 , 57 (2005).

4. M. Sagiroglu and H. Duman, Turkish J. of Botany 30, 399 (2007).

5. M. Sagiroglu and H. Duman, Annales Botanici Fennici 47, 293 (2010).

6. M. Sagiroglu and H. Duman, Botanical J. of the Linnean Society 153 , 357 (2007b).

7. H. Altundag and M. Tuzen, Food and Chem. Toxicol. 49(11), 2800 (2011).
8. H. Altundag and M.S. Dundar, Fresenius Environm. Bull. 18(1), 98 (2009).

9. M.S. Dundar and H. Altundag, Trace Elements and Electrolytes 19(2), 55 (2002).

10. H. Altundag, M.S. Dundar, S. Doganc1, M. Celik, and M. Tuzen, J. of AOAC International 96(1), 166 (2013).

11. M. Tayfur, Ünlüoglu, and Ö. Bener, Food Magazine 27(4), 305 (2002).

12. FAO. Irrigation and Drainage, Rome, Italy, 81, 29 pp. (1985).

13. IPCS Barium. World Health Organization, Geneva, Switzerland, Environmental Health Criteria (107) (1990).

14. RDA, Recommended dietary allowance (10th ed.). Washington, DC: National Academic Press, USA (1989).

15. Joint FAO/WHO, In 53rd Meeting, Rome, Italy, (June 1-10, 1999).

16. World Health Organization, WHO, 197 (1994).

17. World Health Organization, Fortyfirst report of the Joint FAO/WHO Expert Committee on Food Additives, WHO Technical Report Series, 837 (1993).

18. World Health Organization, Geneva, Switzerland (2008).

19. P.S. Nielsen, Bone 35(3), 583 (2004). 